\title{
Potential utilization of glycerol as crosslinker in starch films for application in
}

\section{Regenerative Dentistry}

Potencial utilização de glicerol como reticulador em fillmes de amido para aplicação em

Odontologia Regenerativa

Utilización potencial de glicerol como reticulante en películas de almidón para su aplicación en

Odontología Regenerativa

Received: 11/20/2021 | Reviewed: 11/26/2021 | Accept: 11/27/2021| Published: 12/12/2021

\author{
Simone Rodrigues \\ ORCID: https://orcid.org/0000-0003-4466-2834 \\ Federal University of Uberlândia, Brazil \\ E-mail sijorgerodrigues@gmail.com \\ Mariana Fornazier \\ ORCID: https://orcid.org/0000-0002-0218-5972 \\ Federal University of Uberlândia, Brazil \\ E-mail: mariana-for@hotmail.com \\ Denildo Magalhães \\ ORCID: https://orcid.org/0000-0002-2428-682X \\ Federal University of Uberlândia, Brazil \\ E-mail: seodo@umuarama.ufu.br \\ Reinaldo Ruggiero \\ ORCID: https://orcid.org/0000-0001-7779-3457 \\ Federal University of Uberlândia, Brazil \\ E-mail: ruggiero.reirug.reinaldo@gmail.com
}

\begin{abstract}
Periodontal disease results in damage to dental insertion apparatus. Regenerative procedures are proposed to replace lost structures in the context of guided tissue regeneration (GTR), guided bone regeneration (GBR) techniques and frequently associate bone substitutes with physical barriers aiming at greater longevity and improvement of aesthetic pattern. This study evaluates the possibility of using glycerol as a starch films modifying agent, acting as a cross-linking agent, without compromising its plasticizing effect. Biodegradable cassava starch films were prepared incorporating glycerol at concentrations of $0,15,20,30$ and $40 \%$ aiming application at dental regenerative procedures. The characterization of films by microscopy (SEM), thermal analysis (DSC), spectroscopic (UV / Vis., FTIR, XRD), mechanical (Traction), and analysis of protein swelling, degradation and diffusion and physiological temperature) showed that the incorporation of glycerol in up to $20 \%$ attributed to the films a plasticizer character and in higher concentrations, conferred a greater interaction of glycerol (crosslinking) with the starch chains and a degradation time that allows the physical barrier in RTG and ROG. The films presented mechanical resistance, malleability and permissiveness to protein diffusion in the in vitro assays, which meet the current attributes that guide the use of these resources in biomaterials.
\end{abstract}

Keywords: Crosslinking; Glycerol; Guided tissue regeneration; Starch.

\section{Resumo}

A doença periodontal resulta em danos ao aparelho de inserção dentária. Procedimentos regenerativos são propostos para substituir estruturas perdidas no contexto de técnicas de regeneração tecidual guiada (GTR), regeneração óssea guiada (GBR) e frequentemente associam substitutos ósseos a barreiras físicas visando maior longevidade e melhoria do padrão estético. Este estudo avalia a possibilidade da utilização do glicerol como agente modificador de filmes de amido, atuando como agente reticulante, sem comprometer seu efeito plastificante. Filmes biodegradáveis de amido de mandioca foram preparados incorporando glicerol nas concentrações de $0,15,20,30$ e $40 \%$ visando aplicação em procedimentos regenerativos odontológicos. A caracterização dos filmes por microscopia (SEM), análise térmica (DSC), espectroscópica (UV / Vis., FTIR, XRD), mecânica (Tração), e análise de intumescimento, degradação e difusão e temperatura fisiológica de proteínas mostraram que a incorporação de glicerol em até $20 \%$ atribuiu aos filmes um caráter plastificante e em maiores concentrações, conferiu uma maior interação do glicerol (reticulação) com as cadeias de amido e um tempo de degradação que permite a barreira física em RTG e ROG. Os filmes apresentaram resistência mecânica, maleabilidade e permissividade à difusão de proteínas nos ensaios in vitro, que atendem aos atuais atributos que norteiam a utilização desses recursos em biomateriais.

Palavras-chave: Reticulação; Glicerol; Regeneração tecidual guiada; Amido. 


\section{Resumen}

Periodontal disease results in damage to dental insertion apparatus. Regenerative procedures are proposed to replace lost structures in the context of guided tissue regeneration (GTR), guided bone regeneration (GBR) techniques and frequently associate bone substitutes with physical barriers aiming at greater longevity and improvement of aesthetic pattern. This study evaluates the possibility of using glycerol as a starch films modifying agent, acting as a cross-linking agent, without compromising its plasticizing effect. Biodegradable cassava starch films were prepared incorporating glycerol at concentrations of $0,15,20,30$ and 40\% aiming application at dental regenerative procedures. The characterization of films by microscopy (SEM), thermal analysis (DSC), spectroscopic (UV / Vis., FTIR, XRD), mechanical (Traction), and analysis of protein swelling, degradation and diffusion and physiological temperature) showed that the incorporation of glycerol in up to $20 \%$ attributed to the films a plasticizer character and in higher concentrations, conferred a greater interaction of glycerol (crosslinking) with the starch chains and a degradation time that allows the physical barrier in RTG and ROG. The films presented mechanical resistance, malleability and permissiveness to protein diffusion in the in vitro assays, which meet the current attributes that guide the use of these resources in biomaterials.

Palabras clave: Reticulación; Glicerol; Regeneración tisular guiada; Almidón.

\section{Introduction}

Periodontal disease is characterized as a multifactorial chronic inflammatory disease associated with biofilm presenting clinically with loss of dental insertion apparatus (Pinheiro et al., 2021). The treatment aims at interrupting the tissue destruction in which surgical interventions are presented with the purpose to promote root decontamination and adjust the periodontal structures through the resective and regenerative procedures. Considering the limitations of resective surgeries when using bone reconstructions to eradicate defects (Becker et al. 2001), regenerative techniques are recommended based on improved function and prognosis in the long term, as well as improvement in the esthetic pattern (Boyne 1964).

Gottlow et al., (1986), evaluated the stability of new periodontal insertion achieved through guided tissue regeneration (GTR). This principle, initially called Guided Bone Regeneration (GBR), was described by Hurley et al., in 1959. It is possible to point out the use of tissue barriers in order to inhibit the interference of unwanted cells from adjacent soft tissues during the cicatricial process (Nyman et al.,1989). It is known that fibroblasts activity is much faster than the activity of osteoblasts and with collagen fiber deposition the bone neoformation is not effective, since the space was not physically preserved (Pecora et al., 1997). Studies describe the efficacy of the membranes together with the reconstructive treatment as the result of contact inhibition by the interaction of heterotopic cells in addition to the exclusion of soluble inhibitory factors derived from cells, favoring the local concentration of growth stimulating factors, even combined with properties stimulating the membrane itself (Linde et al., 1993; Andrade Silva et al., 2021).

Scientific investigations report absorbable membranes with certain advantages over the first generation membranes such as better biocompatibility (Williams 1981), precise cell occlusion (Karring et al., 1985), tissue integration (Rothamel et al., 2005) and semi-rigidity when positioned at the interface of the defect and the epithelium (Chen et al. 1997), which collaborate with wound stabilization (Schwarz et al., 2008), transfer of oxygen and nutrients (Schwarz et al., 2006). However, anatomical and technical realities of clinical treatment may result in early exposure of the membrane to the oral medium and consequent bacterial invasion resulting in acute inflammation that is detrimental to osteogenesis (Warrer et al., 1991; Andrade Silva et al., 2021).

Among the materials used for the production of films, starch presents itself as a natural polymer, abundant in nature and biocompatible (Aggarwall \& Dollimore 1998; Silva et al., 2021), having its structure in the form of intracellular spherical granules of 2-100 $\mu \mathrm{m}$ in diameter and having in its composition amylose consisting of a linear chain polysaccharide and amylopectin, with a branched chain ratio of 30 and $70 \%$ respectively (Sing et al., 2007). However, starch films in their native form are brittle and have low moisture barrier properties and high water sensitivity due to their hydrophilic character.

As a consequence of the limitations of native starches, plasticization and modification of the starch is required order to improve their properties and broaden the application possibilities (Srinivasa et al. 2007; Moad 2011; Menzel et al. 2013). One approach taken to modify starch films, for better control of dissolution and degradation of the material, is chemical cross-linking 
(Kim \& Lee 2002; Kou \& Gao 2018; Wu et al., 2019). This process occurs by the addition of cross-linking agents, such as gluteraldehyde, which normally exhibit toxicity (Shi et al., 2008). Thus, for the application of films as biomaterials, the use of non-toxic cross-linking reagents is required.

In this work glycerol was chosen as a modifying agent in starch films, considering that it promotes plasticization, overcoming film fragility and improving flexibility and extensibility (Cruz et al., 2020). In addition, because of its bifunctional structure it can serve as a non-toxic cross-linking agent, through the interaction between glycerol hydroxyl groups and starch hydroxyl groups, improving the water resistibility due to reducing available OH groups of starch (Thiebaud et al., 1997). The purpose of this work was to evaluate the influence of different glycerol concentrations on the properties of starch films aiming their application in dental regenerative procedures.

\section{Methodology}

\subsection{Materials}

Cassava starch (Manihotutilissima) refer to the starch product extracted from the ground and edible parts of the plant, containing approximately $25 \%$ amylose and $75 \%$ amylopectin, was commercially acquired locally, and glycerol from Neon. Phosphate buffered saline (PBS) was prepared by mixing sodium hydroxide (Vetec), sodium dihydrogen phosphate (Carlo ErbaReagents) and deionized water. Bovine serum albumin (BSA) protein was purchased from Sigma Aldrich.

\subsection{Production of films}

The different starch films were developed by the casting method (Gontijo de Melo et al., 2018). From the same concentration of cassava starch $(6 \% \mathrm{~m} / \mathrm{v})$ the glycerol was incorporated in the concentrations $0 \%, 15 \%, 20 \%, 30 \%$ and $40 \%$ $(\mathrm{m} / \mathrm{v})$ relative to the starch mass. For each formulation the starch and the glycerol in the different concentrations were diluted in $100.00 \mathrm{~mL}$ of deionized water and taken to the heating by means of a microwave oven with a power of $30 \mathrm{~W}$ until gelatinization occurred. The remaining solvent $(100.00 \mathrm{~mL})$ was then added and the systems were magnetic stirred for 10 minutes and then they were kept at a rest at room temperature for 24 hours. Finally, the filmogenic solutions were poured into silicone molds and allowed to dry in a hood for a period of 30 hours. At the end of the drying time, the resulting films were removed and stored.

\subsection{Determination of thickness and density}

The films were cut into $1.5 \mathrm{~cm}^{2}$ squares and weighed on analytical balance. Subsequently, the thickness (e) was determined at 3 different points using a ZAAS digital micrometer.

The density (d) was calculated from Equation 1, where "m" is the mass of the film, " $t$ " the thickness (cm) of the sample and "A" the area of the sample (Müller et al. 2008).

$$
d=\frac{m}{V}=\frac{m}{t A}
$$

\subsection{Analysis of humidity absorption}

The films were dried in an oven at $60^{\circ} \mathrm{C}$ for 2 hours, weighed on analytical balance for initial mass determination $\left(\mathrm{m}_{\mathrm{i}}\right)$ and stored in "zip lock" plastics. At different time periods films were removed from the plastics, weighed again to obtain mass gain due to humidity absorption $\left(\mathrm{m}_{\mathrm{h}}\right)$ and stored again until the next weighing period. The humidity absorption was determined by Equation 2.

$$
\text { Humidity absorption }(\%)=\frac{m_{h}-m_{i}}{m_{i}} .100
$$




\subsection{Analysis by scanning electron microscopy (SEM)}

The morphology of the films was analyzed with respect to their surface and cross-sectional surface using the CARL ZEISS MOD EVO MA10 microscope, with an acceleration voltage of $5 \mathrm{kV}$. Prior to analysis, the samples were coated with an ultrafine gold layer in a spray coating system and for cross-sectional surface analysis the samples were previously frozen in liquid nitrogen and fragmented. Analysis of the swollen films without the freezing and metallization procedures was also performed.

\subsection{Analysis by fourier transform infrared spectroscopy (FTIR)}

The infrared transmittance spectra of the films were obtained with a spectrometer FT-IR Spectrometer Frontier with attenuated total reflectance (ATR) accessory, in the range of 4000 to $650 \mathrm{~cm}^{-1}$, with a resolution of $4 \mathrm{~cm}^{-1}$.

\subsection{Differential scanning calorimetry (DSC)}

The analysis were performed on a Q-20 model, TA Instuments, in a scan. The films, about $7.00 \mathrm{mg}$, were heated from $25{ }^{\circ} \mathrm{C}$ to $175^{\circ} \mathrm{C}$, both at a heating rate of $10^{\circ} \mathrm{C} \mathrm{min}^{-1}$, under an atmosphere of nitrogen with flow of $50 \mathrm{~cm}^{3} \mathrm{~min}^{-1}$.

\subsection{X-ray diffraction analysis (XRD)}

The X - ray diffraction analysis was performed in a Shimadzu XRD - 6000 LabX diffractometer, operating at a power of $40 \mathrm{kV}$ with $30 \mathrm{~mA}$ of current and radiation of $\mathrm{Cu} \mathrm{K \alpha}(1.5406 \mathrm{~A})$. The $2 \theta$ scan data were collected from $5^{\circ}$ to $35^{\circ}$ at a scanning speed of $1^{\circ} \min ^{-1}$.

The relative crystallinity index (CI) was quantitatively estimated as proposed by Rocha et al., (2008), based on the ratio of the area of the crystalline region and the total area covered by the curve, composed by the area of the crystalline region $\left(\mathrm{A}_{\mathrm{c}}\right)$ and the area of the amorphous region $\left(\mathrm{A}_{\mathrm{a}}\right)$, according to Equation 3:

$$
C I(\%)=\frac{A_{c}}{A_{c}+A_{a}} \cdot 100
$$

\subsection{Analysis of mechanical properties}

The mechanical properties of the films (tensile strength, Young's modulus and elongation at break) were evaluated by uniaxial tensile test using an Instron universal model 5982 mechanical test apparatus with a load cell of $5.00 \mathrm{kN}$. The films were cut into strips of $1.00 \mathrm{~cm}$ wide by $4.00 \mathrm{~cm}$ in length, fixed in the apparatus and subjected to the stress and strain test with a velocity of $25.00 \mathrm{~mm} \mathrm{~min}^{-1}$ and distance between the claws of $3.00 \mathrm{~cm}$.

\subsection{Analysis of swelling and degradation at physiological pH}

Swelling and degradation were analyzed under conditions close to the post-surgical environment at physiological $\mathrm{pH}$, which was simulated using a solution of phosphate buffered saline (PBS), whose $\mathrm{pH}=7.4$ is similar to the $\mathrm{pH}$ of the blood $(\mathrm{pH}=7.35)$.

The swelling behavior was evaluated by the gravimetric method (Doulabi et al., 2013). The films were weighed ( $\mathrm{w}_{\mathrm{d}}$ ) and then immersed in $10.00 \mathrm{~mL}$ of PBS at $36.5^{\circ} \mathrm{C}$. After distinct periods of time, the films were removed from the PBS, placed on paper towel to remove excess liquid and immediately weighed $\left(\mathrm{w}_{\mathrm{m}}\right)$. The swelling ratio of the films was calculated using Equation 4. 
For the degradation studies, film samples were initially weighed $\left(\mathrm{w}_{\mathrm{o}}\right)$, immersed in degradation media containing PBS and incubated at $36.6^{\circ} \mathrm{C}$ for several weeks. After each time interval the films were removed and completely dried before being reweighed $\left(\mathrm{w}_{\mathrm{t}}\right)$. The mass loss was calculated using Equation 5 and the time required for total degradation of the films was determined by the equation of the line obtained from the graph of mass variation according to the time (Figure S12 Supplementary Material).

$$
\begin{aligned}
& \text { Swellingrate }(\%)=\frac{w_{w}-w_{d}}{w_{d}} \cdot 100 \\
& \text { Weightloss }(\%)=\frac{w_{o}-w_{t}}{w_{o}} \cdot 100 \%
\end{aligned}
$$

\subsection{Protein diffusion study}

The protein diffusion study was performed using bovine serum albumin (BSA) as a model. For this, a calibration curve was constructed with known concentrations of BSA in PBS, considering BSA had a maximum absorption at $280 \mathrm{~nm}$ (Zaia et al., 1988), (Figure S13 - Supplementary Material).

Diffusion of the BSA protein was analyzed using an identical two-compartment system separated by discrete film samples containing one-side PBS and a BSA solution with a concentration of $2.00 \mathrm{mg} \mathrm{mL}^{-1}$ in PBS on the other side. At different time periods aliquots of $3.00 \mathrm{~mL}$ of solution were collected at the same point in the compartment containing only PBS solvent and its UV/Vis absorbance was determined in a spectrophotometer (Shimadzu, model UV 2501 PC) at wavelength $280 \mathrm{~nm}$, the maximum absorption of BSA in this solution, determined previously.

\section{Results and Discussion}

\subsection{Determination of thickness and density}

Biodegradables starch films were produced by the casting method, resulting in translucent, homogeneous, depigmented samples without the presence of lumps or bubbles (Figure 1). The flexibility of the films varied according to the glycerol content.

Figure 1. Films of cassava starch with glycerol in the concentrations of: (a) $0 \%$, (b) $15 \%$, (c) $20 \%$, (d) $30 \%$ and (e) $40 \%$.

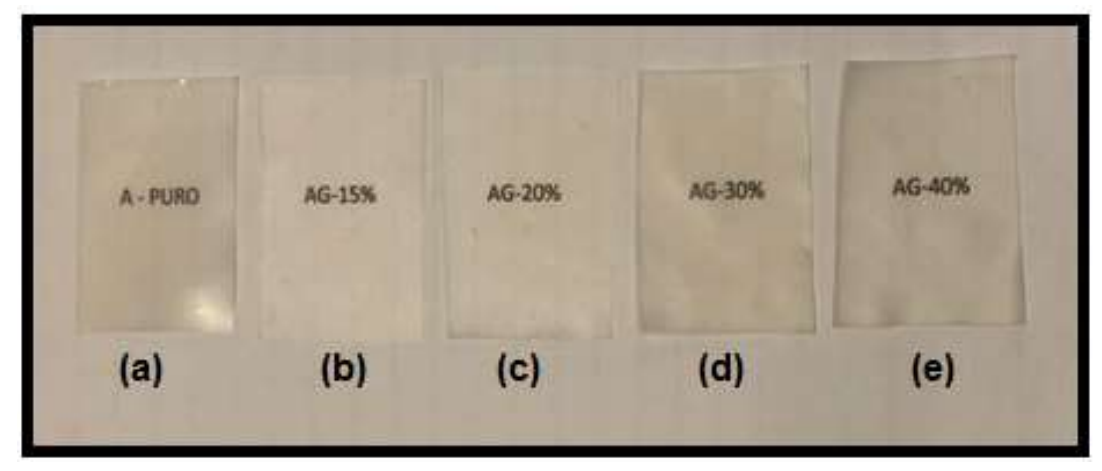

Source: Authors.

The thickness of the films ranged from $0.174 \mathrm{~mm}$ to $0.229 \mathrm{~mm}$, with significant differences between the formulations (Figure 2). The addition of glycerol led to an increase in film thickness due to the higher mass in the polymer matrix. With respect to density (Figure 2) one can observe an inverse behavior to the thickness data. At the beginning, with the incorporation of glycerol in $15 \%$ and $20 \%$, an increase in the thickness on the one hand, and the decrease in density, on the other hand, are 
observed. Until the concentration of $20 \%$ the interaction with the glycerol, does not seem to occur in an effective way, since the small increase of mass does not imply in decrease of the volume of the system. Above $20 \%$, this phenomenon begins to reverse, suggesting a probable process of physical crosslinking, which reduces the empty spaces of the starch matrix.

Figure 2. Effect of glycerol concentration on density and thickness of films.

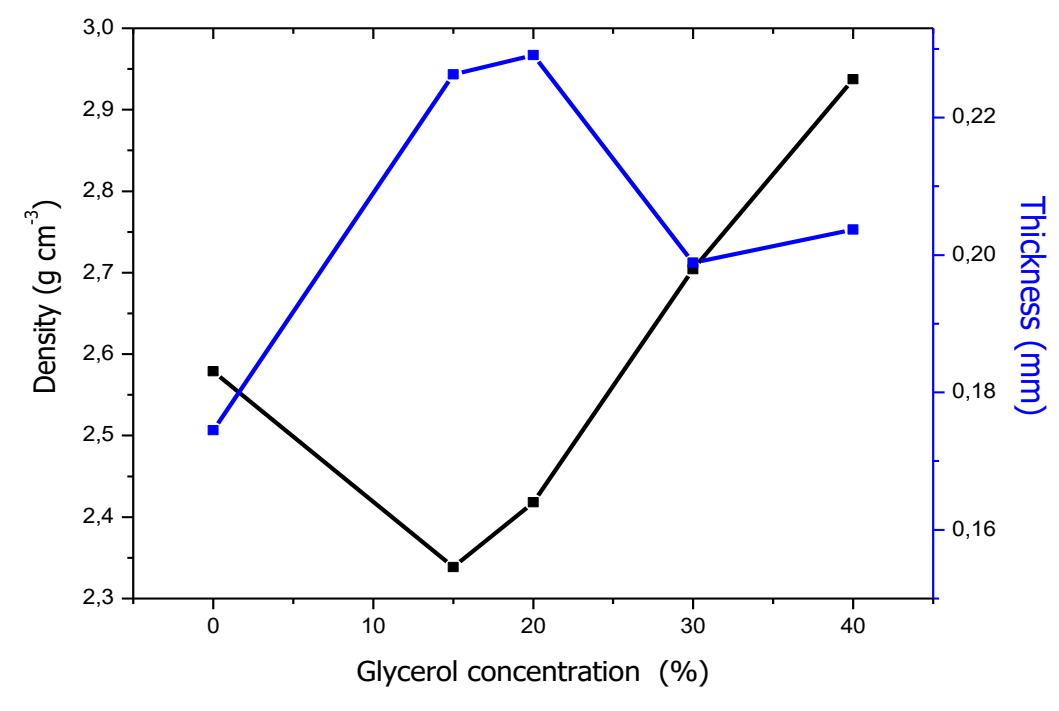

Source: Authors.

Films prepared in the presence of glycerol exhibited thickness and malleability favorable to handling suggesting adequate application. The clinical control can be determined by the ease of surgical manipulation, setting a format favorable to the operative handling. In more complex anatomical situations, the adaptation of a two-dimensional membrane on a threedimensional surface may require of the film certain rigidity or memory to remain modelled to the bone contour, resulting in a more complete bone regeneration.

\subsection{Analysis of humidity absorption}

Films prepared in the presence of glycerol exhibit increased humidity absorption, as shown in Figure 3. This increase is related to the hydrophilic character of the glycerol that allows a greater interaction of the film with the water present in the environment (humidity). 
Figure 3. Humidity absorption of the starch films with different concentrations of glycerol.

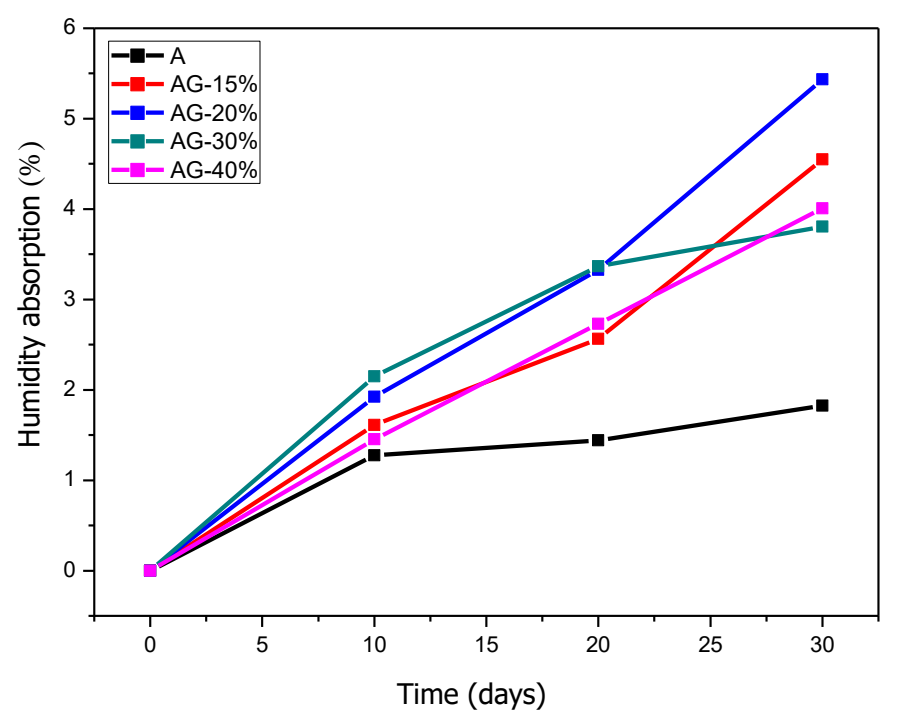

Source: Authors.

It was expected that with higher concentrations of glycerol the humidity absorption would be higher, but this was only observed for the samples with glycerol content of up to $20 \%$. This change is due to the intensification of glycerol-starch interactions, which hinder the interaction of glycerol molecules with water. This effect confirms the strong crosslinking bet ween starch and glycerol, when the concentration of glycerol exceeds 20\%, as observed in the data of density and thickness (Figure 2).

As for the application of films, the rate of humidity absorption should not be a problem, since they can be stored in sealed packages without contact with the environment.

\subsection{Analysis by scanning electron microscopy (SEM)}

In order to obtain more information on the morphology of the films under study, SEM analysis was performed. The analysis may illustrate the impact of glycerol incorporation on the structure of cassava starch films. Surface and cross-section (fracture) micrographs of dry and swollen films are shown in Figure 4. The images of the dry samples have different structural patterns. The first two films (A and AG-15\%) look very similar to both surface and cross-sectional images, whereas in AG-20\% film the images change radically with the appearance of striations.For the most concentrated films in glycerol (AG-30\% and AG40\%), the aspect changes again. On the surface clarification of the image occurs as the concentration of glycerol increase.

It is also noted in the of cross-sectional images that the AG-30\% film presents wide vertical channels in all its extension from the surface and the film AG-40\% presents an intense increase of thinner channels in all directions and in all extension transverse.The micrographs of the swollen samples also show structural alterations, with the occurrence of large vertical fringes on the surface in A and transverse in AG-15\%. In the sample AG-20\%, AG-30\% and AG-40\%, the fringes are drastically reduced both at the surface and in the cross-section appearing greater homogeneity.Another notable fact is the progressive clarification on the surface of the samples as the concentration of glycerol increase. 
Based on the superficial texture of the films produced and with respect to the integration of these to adjacent tissues in the repair process, we can expect them to be viable to this requirement. The biomaterial must provide a chemical structure that favors the growth of connective tissue or the insertion to the membrane during the healing process, promoting tissue integration (Somerman et al., 1991; Andrade et al., 2021).

Analyzing the micrographs, it is possible to notice that the films, regardless of the formulation used, do not have pores on their surface and along their cross section, with homogeneous regions being observed. The transport of nutrients through the membrane is suggested by the permissiveness to the protein diffusion in the assays at physiological $\mathrm{pH}$.

Figura 4. MEV micrographs of films: (A) surface for dry films (1000x), (B) cross section for dry films (1000x), (C) surface for swollen films (100x) and (D) cross section for swollen films (500x).

(A)

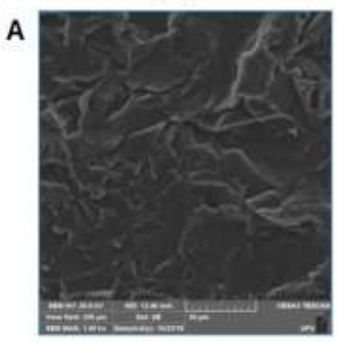

AG-15\%

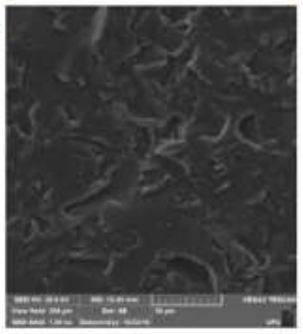

AG-20\%
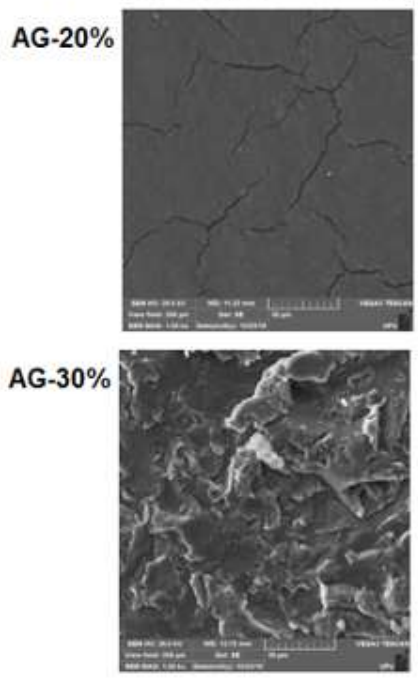

AG $-40 \%$

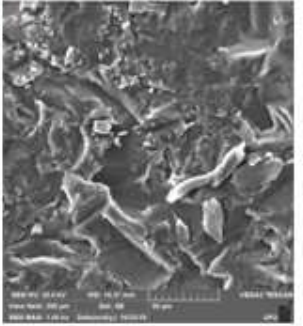

(B)
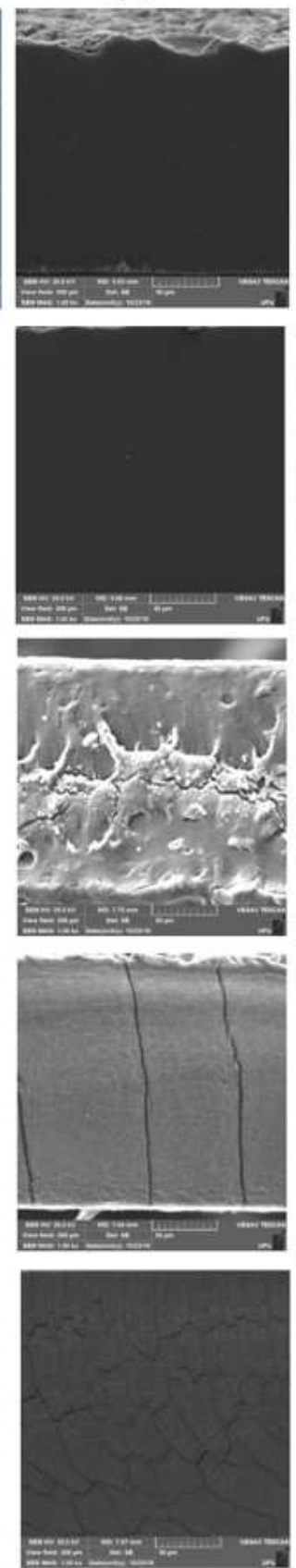

(C)
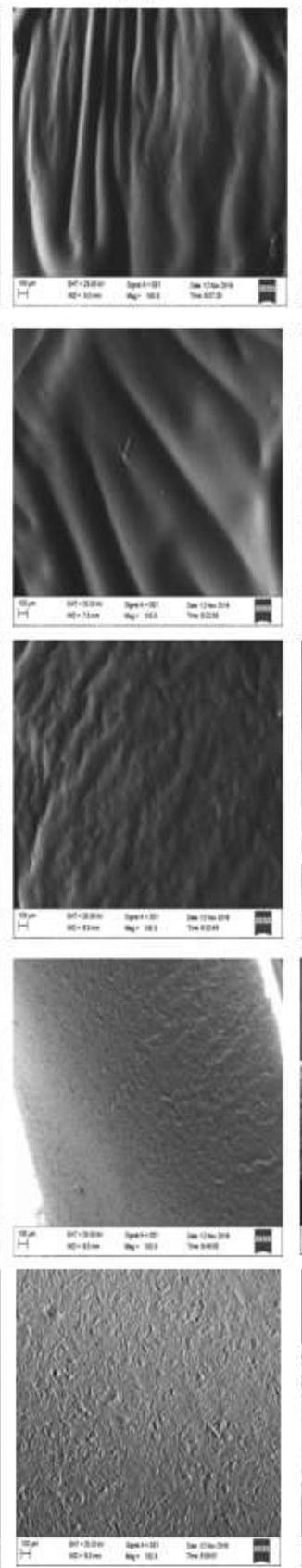

(D)
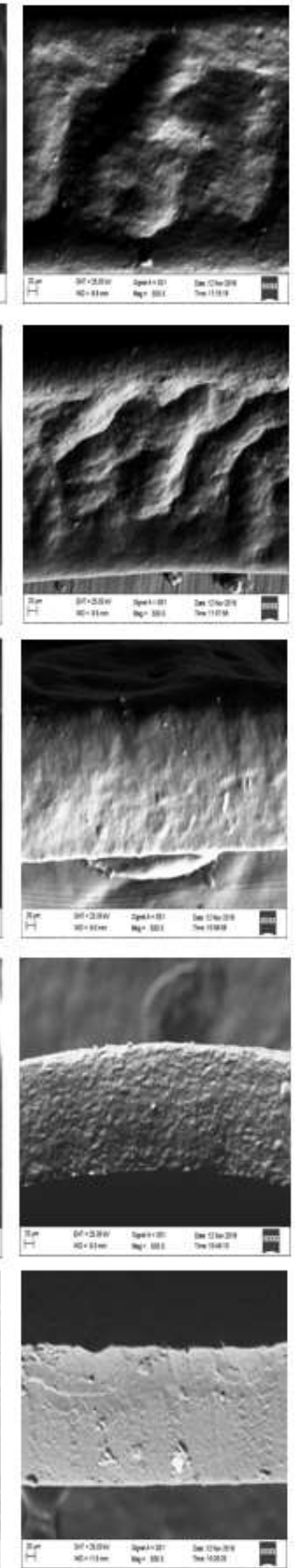

Source: Authors. 


\subsection{Analysis by fourier transform infrared spectroscopy (FTIR)}

FTIR spectroscopy was performed to determine the interactions between the starch matrix and glycerol. The spectra of the films are shown in Figure 5. The films presented spectra in characteristic bands: a) $3467 \mathrm{~cm}-1$ at $3151 \mathrm{~cm}-1$, a range attributed to the stretching of free $\mathrm{OH}$ groups and associated with intra and intermolecular hydrogen bonds formed from hydroxyl groups of starch and glycerol; b) $2994 \mathrm{~cm}^{-1}$ at $2950 \mathrm{~cm}^{-1}$, range attributed to the stretching of the $\mathrm{C}-\mathrm{H}$ group present in the polymer matrix; c) $1690 \mathrm{~cm}^{-1}$ to $1589 \mathrm{~cm}^{-1}$, the range attributed to the water absorbed by the starch molecules; d) $1346 \mathrm{~cm}^{-1}$, attributed to glycerol molecules; and e) $1167 \mathrm{~cm}^{-1}$ at $930 \mathrm{~cm}^{-1}$, range attributed to $\mathrm{C}-\mathrm{O}$ stretching at $\mathrm{C}-\mathrm{O}-\mathrm{H}$ and $\mathrm{C}-\mathrm{O}$ at $\mathrm{C}-\mathrm{O}-\mathrm{C}$ bonds, respectively (Wolkers et al., 2004; Jaramillo et al., 2016).

Figure 5. FTIR spectra of the starch films with different concentrations of glycerol.

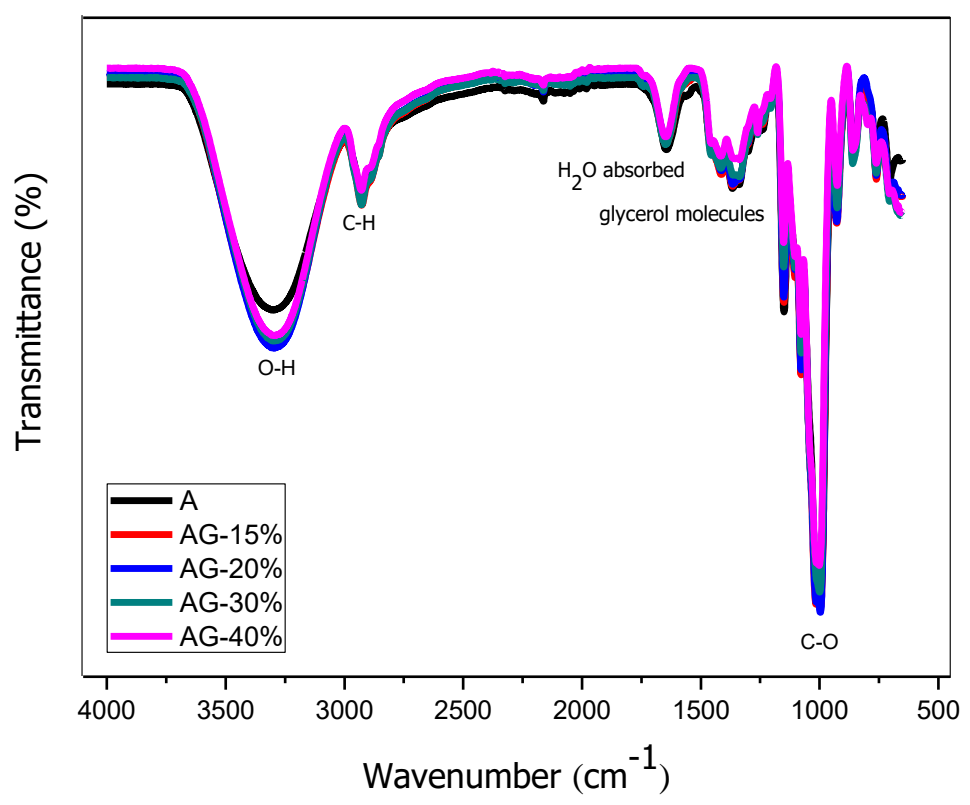

Source: Authors.

In general, the FTIR spectra of the films show the same principal main peaks with some variations in peak amplitude in certain regions, as the glycerol concentration increases. These modifications are more pronounced in the band related to hydroxyl groups, which increase in intensity due to the formation of hydrogen bonds between the starch and glycerol chains promoted by the crosslinking process.

\subsection{Differential exploration calorimetry (DSC)}

The DSC curves of the starch films (Figure 6) were analyzed to determine the differences in the thermal behavior of the materials with regard to the elimination of water. It is observed through the DSC curves that all films have profiles with occurrence of endothermic peaks, with some changes in maximum temperatures and intensity, through the incorporation of glycerol. In Figure 6(A), we have the occurrence of an endothermic peak, around $100{ }^{\circ} \mathrm{C}$, attributed to the water exit of the structure of the films. Note that films containing glycerol exhibit a displacement of this peak at higher temperatures in Fig. 6(B), indicating that water is associated with the other components of the films, at different intensities of interactions. 
Thus, it is observed that water retention increases as the amount of glycerol in the film increases, except for the AG$40 \%$ sample, where there is a small decrease in temperature. The graph for these data in Figure 6(B), also shows that this increase in temperature occurs more slowly at concentrations above $20 \%$ glycerol and decrease from $30 \%$, validating the previous discussions, where it is concluded that above $20 \%$ of glycerol, there is a growing attractive interaction between starch and glycerol, which makes the interaction of the sample with water less intense.

Figure 6. (A) DSC thermograms for starch films and (B) Maximum water outlet temperature of the films.
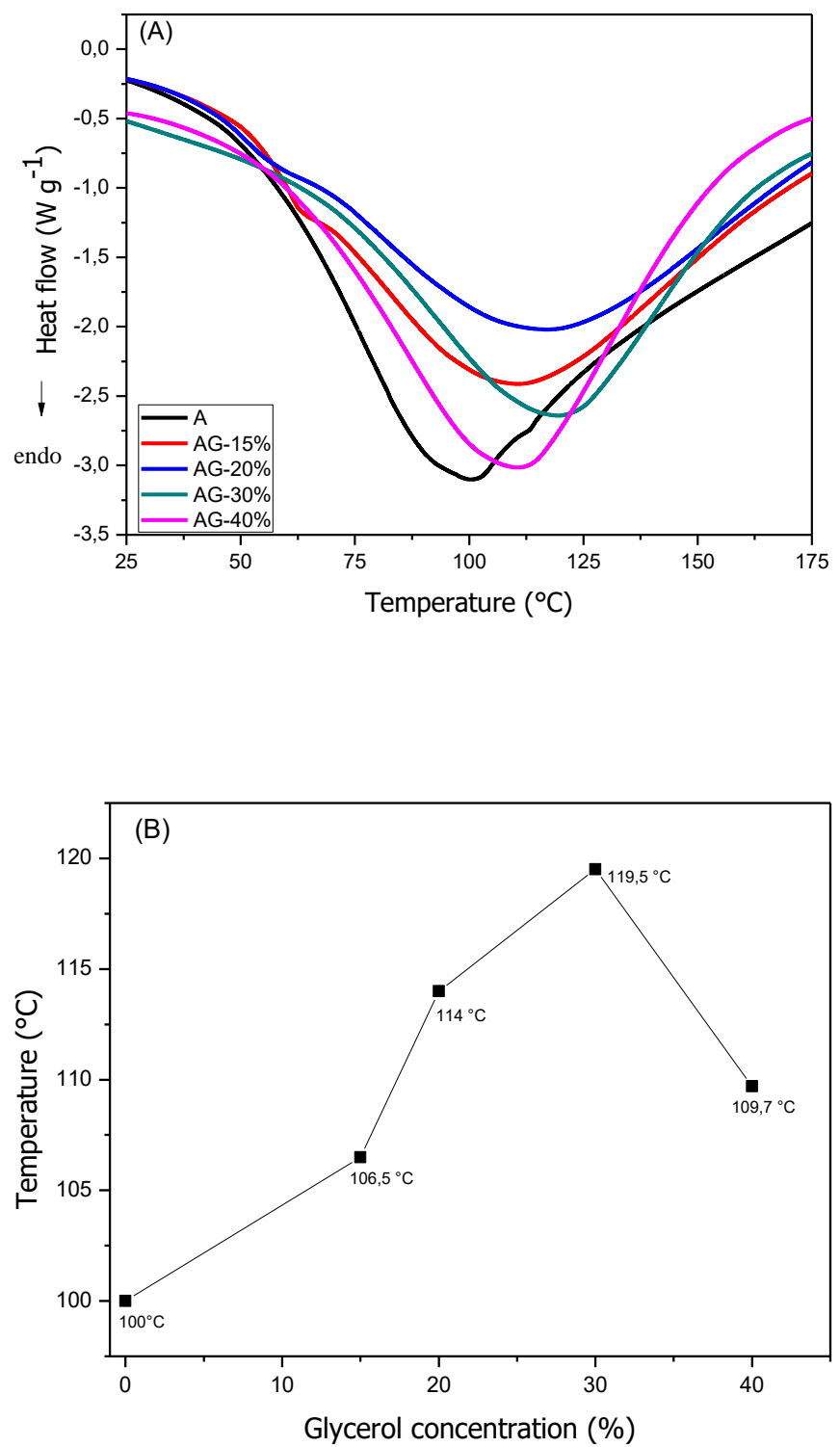

Source: Authors.

\subsection{X-ray diffraction analysis (XRD)}

The structural analysis of the films was obtained by XRD and the results are shown in Figure 7. 
Figure 7. X-ray diffraction patterns of the starch films with the studied glycerol concentrations.

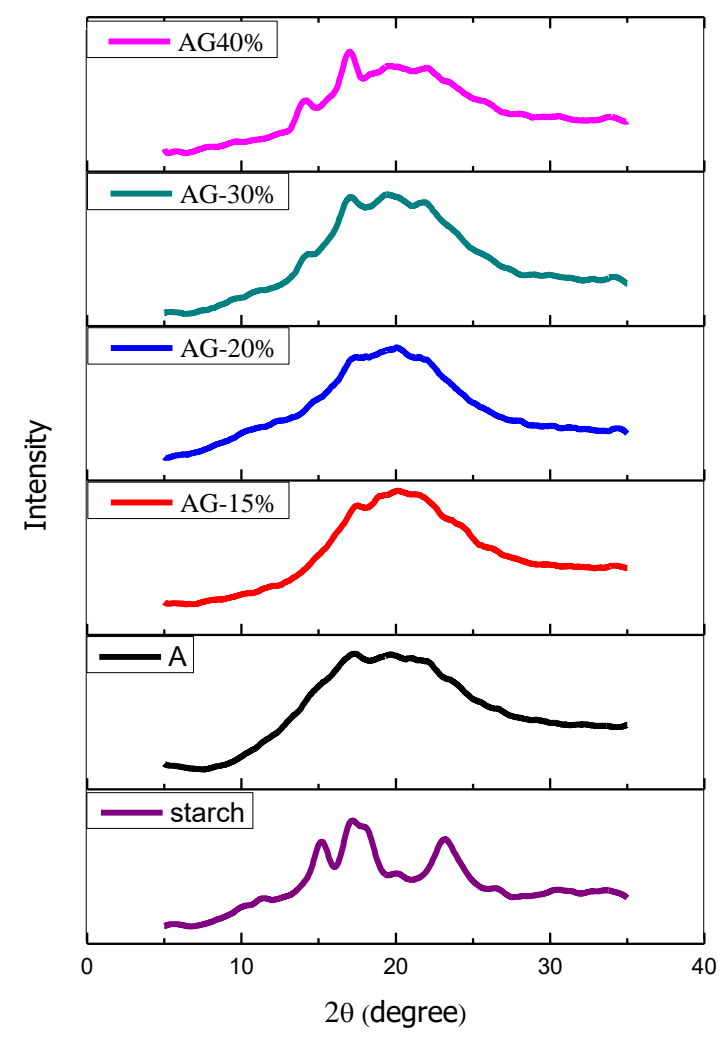

Source: Authors.

The starch granules have different types of crystallinity, such as types A, B or C, depending on the length of the amylopectin branched chains, described mainly due to the double helix formed (Jane 2006; Rengadu et al., 2020). The diffractogram of the starch granule showed six main peaks around the diffraction angles of $11,15,17,18,20$ and $23^{\circ}$ and a 1 ow intensity peak around the diffraction angle of $5.5^{\circ}$, which are characteristic of the starch type CA, due to the greater similarity of the peaks with the type A pattern (Kawabata et al., 1984; Moorthy 2002; Rengadu et al., 2020).

The process of gelatinization of the starch to elaborate the films resulted in the loss of its structural order, with change in the intensity of the reflection peaks, remaining only a small intensity peak occurring around the angle of diffraction of $17^{\circ}$ for the films A, AG $-15 \%$ and AG-20\% and around $14^{\circ}$ and $17^{\circ}$ for AG-30\% and AG-40\% films.

The differences between the films can be explained by the presence of glycerol, which favors the reorganization of the amylose and amylopectin chains, through its interaction with the hydroxyls present in the starch molecules. This process is dependent on the glycerol content, as it can be verified by the IC data (Table 1). In this case, at concentrations up to $20 \%$, glycerol acts predominantly as a plasticizer (Chang et al., 2006). In this case, it interacts with the polymer matrix, but less intensely, as seen in the density data, thus increasing the mobility of its polymer chains. Above $20 \%$, however, glycerol begins to act as a crosslinking agent, promoting the approximation of the polymer chains due to the intensification of the intermolecular strachglycerol interactions. 
Table 1. The effect of glycerol concentration on the crystallinity index (CI), ultimate tensile stress, elongation at break and Young's modulus of the films.

\begin{tabular}{ccccc}
\hline Samples & CI $(\%)$ & $\begin{array}{c}\text { Ultimate tensile } \\
\text { stress }(\mathrm{Mpa})\end{array}$ & $\begin{array}{c}\text { Elongation at } \\
\text { break }(\%)\end{array}$ & $\begin{array}{c}\text { Young's modulus } \\
(\mathrm{Mpa})\end{array}$ \\
\hline starch & 12 & - & - & - \\
A & 0,8 & $48,56 \pm 0,50$ & $3,51 \pm 0,34$ & $2.688,93 \pm 8,60$ \\
AG-15\% & 0,85 & $6,17 \pm 0,23$ & $47,68 \pm 0,15$ & $458,03 \pm 4,36$ \\
AG-20\% & 0,7 & $3,50 \pm 0,09$ & $86,58 \pm 0,04$ & $124,55 \pm 1,51$ \\
AG-30\% & 0,9 & $3,57 \pm 0,16$ & $65,64 \pm 0,21$ & $37,36 \pm 0,79$ \\
AG-40\% & 4,3 & $2,58 \pm 0,13$ & $63,70 \pm 0,11$ & $15,65 \pm 1,36$ \\
\hline
\end{tabular}

Source: Authors.

\subsection{Analysis of mechanical properties}

The evaluation of the mechanical properties of the films in relation to their tensile strength and deformation capacity were performed to verify the influence of the incorporation of the glycerol and to correlate the results obtained with its application. The parameters of the ultimate tensile stress, elongation at break and Young's modulus are shown in Table 1. The stress-strain characteristic curves of the films are shown below (Figure 8).

The incorporation of the glycerol to the starch matrix induced a mechanical behavior of the films, which varied from brittle to ductile. This change is due to the plasticizing character of glycerol, which reduces the stiffness of the polymer matrix, as shown by the values of modulus of the elasticity, causing sliding between the starch chains and thus favoring the deformation of the film during the application of the tension. Thereby, it was expected that with the addition of the glycerol concentration the deformation rate would be higher, however this behavior is only valid up to the $20 \%$ concentration. Above this concentration the crosslinking effect of glycerol begins to overlap with its plasticizing effect due to the intensification of its interaction with the starch chains, which results in the formation of a structure less resistant to traction and deformation. This effect is also due to the presence of larger portions of crystalline regions in the structure of the films when high concentrations of glycerol are incorporated, as shown by the values of crystallinity index (Table 1).

Figure 8. Stress vsstrain curves of films (Zoom for films with glycerol).

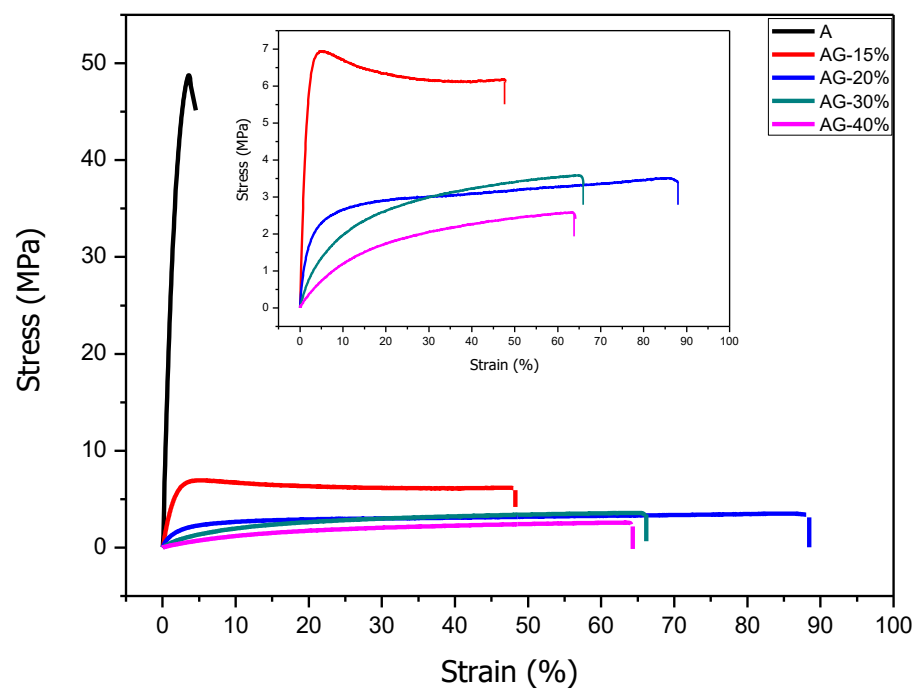

Source: Authors. 
From the results of resistance and elongation, it can be suggested that the films prepared in this study present favorable characteristics to the application in the context of alveolar bone regeneration, for example, where the anatomical, mechanical and technical realities of the clinical treatment may require of the membrane a behavior which guarantees the creation of space, adequate volume and geometry maintenance by supporting their own weight and resisting the pressure exerted by the overlapping tissue and external forces such as mastication. Membrane collapse results in the elimination of the required space, which may impair regeneration (Kohavi et al., 1991) or result in early exposure of the membrane to the oral medium in the course of treatment.

\subsection{Analysis of swelling and degradation at physiological PH}

The results of the swelling and mass loss studies of the starch films in phosphate buffered saline (PBS) are shown in Figure 9.

The swelling process of the films occurs by the spacing between the starch chains due to the retention of the molecules of the solvent PBS, which promote reduction in the intermolecular attraction forces, thus increasing the motility of the starch matrix chains. As the glycerol is incorporated into the polymer matrix, the swelling kinetics of the films is altered as seen in the Figure 9(A). Films with no and low glycerol content exhibit very close kinetics, even after a long time of contact with the simulated body fluid. AG-20\% film has a peculiar kinetic behavior since up to 35 minutes in contact with the fluid, it swells less than AG-40\% and up to 60 minutes, less than AG-30\%.

But the film AG-15\%, from this time, it starts to swell more. In the two films most concentrated in glycerol, from 20 minutes the kinetics of swelling decreases significantly to a state close to equilibrium after 2 hours of immersion. The results also show that the presence of glycerol reduces the swelling ability of the films, since glycerol acts as a crosslinking agent in the starch, installing itself between amylaceous chains, favoring these interactions, permitting less space available for PBS to flow. 
Figure 9. Influence of glycerol concentration on (A) rate of swelling, (B) loss of mass of starch films.
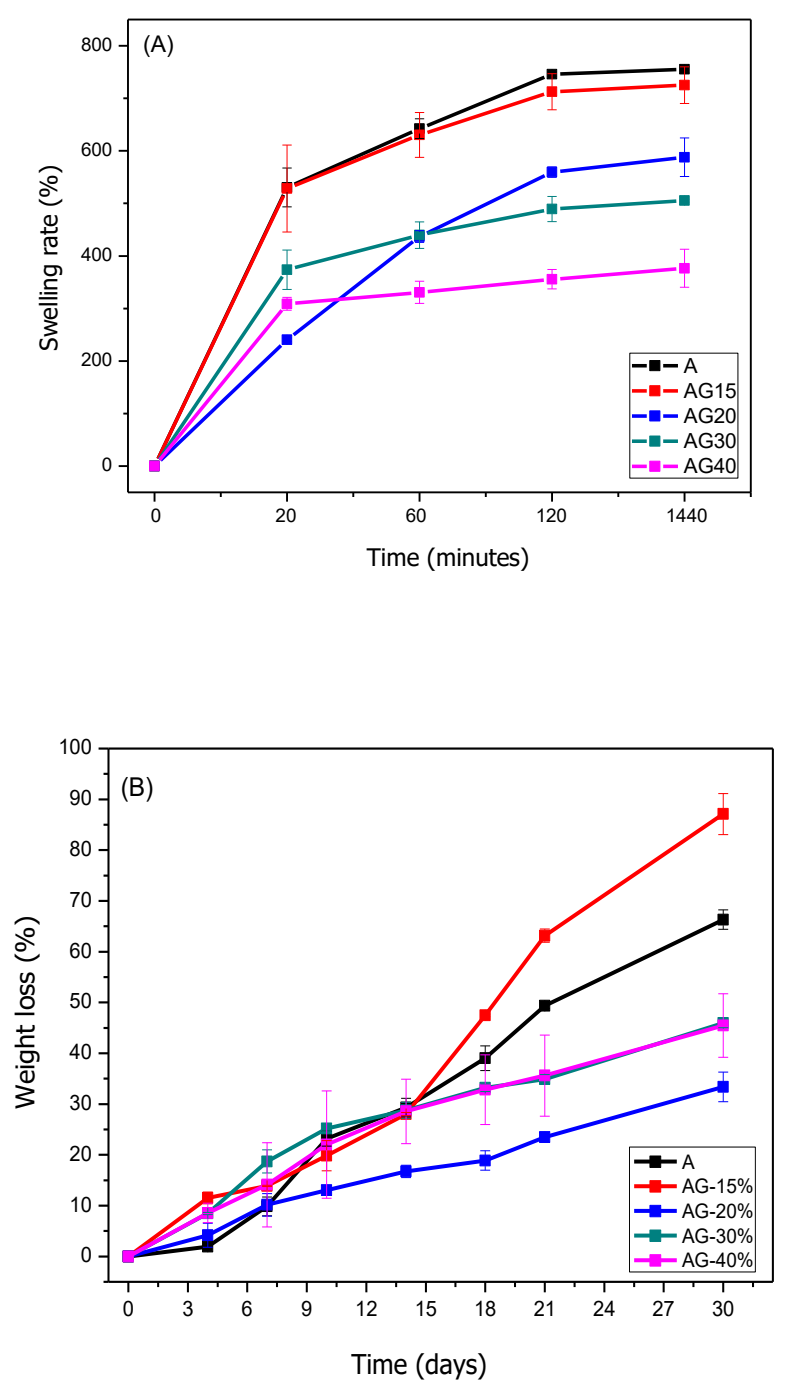

Source: Authors.

Concerning the study of mass loss, which was used to evaluate the degradation profile of the films, it was verified that the presence of the glycerol and the concentration in which it is incorporated affects differently the capacity of loss of mass. After 30 days of analysis, in the film with lower content of glycerol, AG-15\%, the loss of mass was greater than in the film without glycerol (increasing from 50\% to 63\%) and in the films with higher contents, AG-30\% and AG-40\%, it was lower (it was reduced to approximately $35 \%$ in both).

These changes are a consequence of the double effect promoted by glycerol, plasticizer and crosslinking. When the plasticizing effect predominates we have an increase in the mass loss capacity due to the hydrophilicity of the glycerol that favors the interaction of the starch matrix with the solvent PBS, but when the crosslinking effect predominates this interaction is difficult since glycerol is interacting effectively with the starch chains and thus it is not available to interact with the solvent as verified by the swelling study. The AG-20\% film presents a borderline behavior between plasticizer and crosslinking effects, which gives it the odd properties as observed in previous characterizations. 
In respect to the results of figures $9(\mathrm{~B})$ and 10, we can deduce that the films produced with concentrations of glycerol from $20 \%$ presented degradation rates compatible with the requirement of tissue barrier, except for the AG-20\% film that despite presenting the lowest loss of mass did not maintain its structural integrity, exhibiting a gelatinous appearance after 30 days.

The films can be classified as absorbable, considering the estimated period of time for their total degradation (Table 2). The polymeric materials commonly suggested in the constitution of membranes, are degraded by the hydrolysis process and are clearly affected by the environment of the organism, so a degradation that does not promote damage to regenerating tissues is one of the first functions required in this category of biomaterials (Bostman, 1992).

In the RTG and ROG procedures the degradation rate is an essential parameter, since the membrane plays the role of tissue barrier, so it must remain intact by separating the bone tissue from the connective tissue by 3 at 4 weeks, a period in which there is probable formation of immature bone tissue at the site of the defect (Gerzson et al. 2016). The formation of an embryonic bone begins at the surface of the bone matrix, and propagates towards the interior of the defect (Hollinger \& Chaudhari, 1992). By doing so the distance to be covered by the bone regeneration will determine the time in which the membrane should remain in place and functionally intact.

Figure 10. Photograph of the starch films after 30 days: (A) in solution and (B) after removal of the solution.

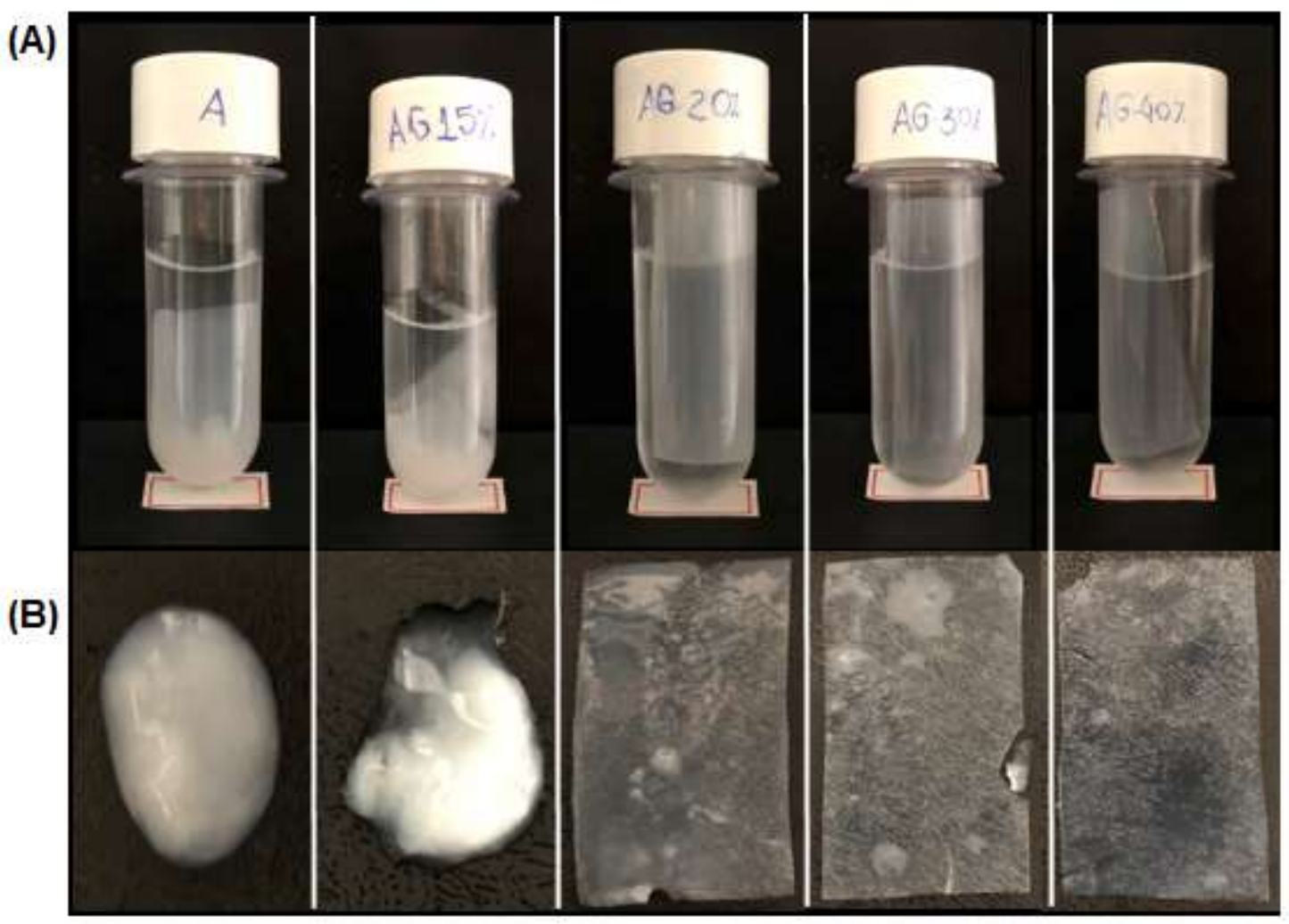

Source: Authors. 
Table 2. Estimation of the total degradation time in PBS of the glycerol crosslinked starch films.

\begin{tabular}{ccc}
\hline Samples & $\mathbf{R}^{\mathbf{2}}$ & \multicolumn{2}{c}{ Estimated end time (days) } \\
\hline A & 0,9848 & 44 \\
AG-15\% & 0,9691 & 35 \\
AG-20\% & 0,9884 & 92 \\
AG-30\% & 0,9357 & 65 \\
AG-40\% & 0,9737 & 63 \\
\hline
\end{tabular}

Source: Authors.

\subsection{Analysis of protein diffusion}

The results obtained regarding to the diffusion profile and the amount of BSA diffused by the films are shown respectively in Figure 11 and in Table 3. As it can be seen in the graph, the film A presents a high diffusion rate in the period between 4 and 24 hours. As the concentration of glycerol increases, the diffusion of the BSA decreases. The data also show that in the first 4 hours, the films A and AG-15\% have the lowest rates of protein diffusion (BSA), whereas the films with higher amount of glycerol presented higher diffusion rates, being AG-20\%> AG-30\%> AG-40\%.

Figure 11. Diffusion profile of BSA by means of the films as a function of time.

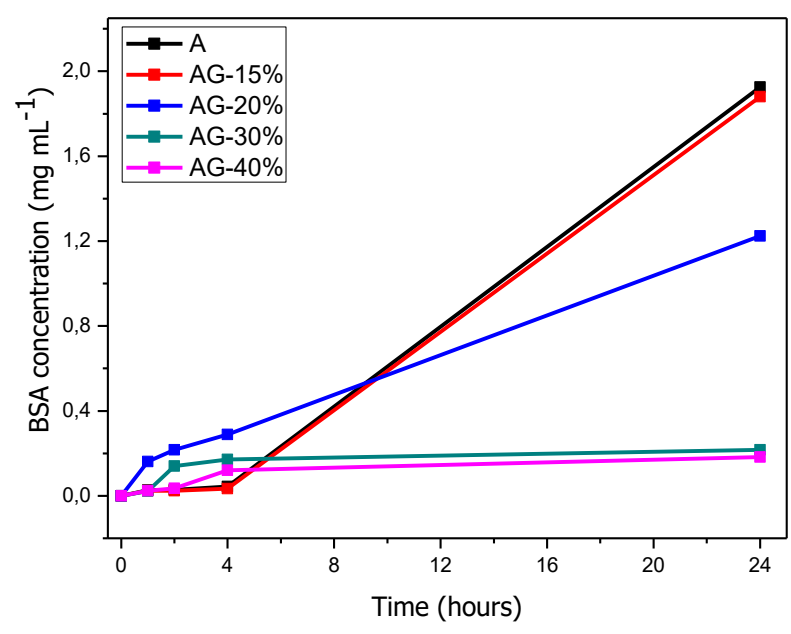

Source: Authors.

Table 3. Amount of BSA diffused through the films as a function of time.

\begin{tabular}{|c|c|c|c|c|c|}
\hline \multirow{2}{*}{ Time (hours) } & \multicolumn{5}{|c|}{ Amount of BSA diffused (mg mL $\left.{ }^{-1}\right)$} \\
\hline & $\mathbf{A}$ & AG-15\% & AG-20\% & AG-30\% & AG-40\% \\
\hline 1 & 0,02653 & 0,02359 & 0,16192 & 0,02285 & 0,02396 \\
\hline 2 & 0,02744 & 0,02396 & 0,21703 & 0,13987 & 0,03553 \\
\hline 4 & 0,04306 & 0,03388 & 0,28831 & 0,17092 & 0,1204 \\
\hline 24 & 1,9253 & 1,88067 & 1,2241 & 0,21703 & 0,18249 \\
\hline
\end{tabular}

Source: Authors. 
After 4 hours this behavior is reversed and the films with higher amounts of glycerol are those that present smaller diffusions, since in long period of time these films tend to have less permissiveness to the diffusion of the protein. This fact probably has to do with the greater crosslinking occurring in high concentrations of glycerol, as seen in the previous results, leading to a more attractive interaction between the components of the same, reducing the possibility of BSA diffusion. Further more, at concentrations above $20 \%$, the polymer network tends to become denser, as shown by the density data, and hence less permeable to the protein.

It has been suggested that membranes used in bone regeneration have properties that allow the transfer of fluid and gaseous nutrients, providing ample nutrition to the graft (Boyne, 1969). The films prepared with the starch do not present visible pores in their structure, however, the findings demonstrated that there is transfer of proteins through diffusion according to the results presented in (Figure 9). The transfer through the membrane is due to the difference in chemical potential due to the concentration gradient. The direction in which these gradients would be established and would be of sufficient magnitude to result in the diffusion of quantities of physiologically significant substances into the regenerating tissues still require other studies that quantify and better qualify these gains.

Based on these results, it was observed that the films presented permissiveness to the diffusion of proteins that are similar to those organically present in the regenerative processes of ROG and RTG.

Considering that starch is a natural vegetable material, easily accessible and inexpensive, because it presents control of the production process and characteristics that make it biologically viable, the use of starch film is suggested as a resource in biomaterials, although future studies are needed, such as: cytotoxicity, cell proliferation and in vivo evaluations.

\section{Conclusion}

Within the proposed methodology and the limitations of this in vitro study, we can conclude that:

- The films of cassava starch and glycerol at concentrations above $20 \%$ present characteristics that suggest that they are applied as a barrier in ROG and RTG having properties such as, mechanical resistence, permissiveness to protein diffusion and degradation in a viable period to the process of repair and regeneration.

- Glycerol exhibits a double behavior since at concentrations below $20 \%$ there is a predominance of the plasticizer character and in the concentrations of 30 and $40 \%$ there is a predominance of the crosslinking effect.

- The AG-30\% and AG-40\% films have a stable behavior maintaining the physical integrity and presenting sufficient degradation time to be used in RTG and ROG, resulting from the crosslinking process.

Based on the results obtained, the development of new studies on the topic addressed is of great value as it will support further discussions on strategies for Obtaining physically crosslinked starch films. Thus, it is proposed for future work to optimize the physical crosslinking of starch using glycerol in concentrations from $30 \%$ in relation to the polymer mass.

\section{Acknowledgments}

The authors thank FAPEMIG (Foundation for Research Support of the State of Minas Gerais), CAPES (Coordination for the Improvement of Higher Level Personnel), CNPq (National Research Council), GMIT-UFU (Triangle Inorganic Materials Group), technical support in FTIR analys, FETI-UFU (School of Chemical Engineering), technical support in the analysis of SEM, Faculty of Civil Engineering for technical support in traction analyzes and the Multiuser Laboratory of the Institute of Chemistry of the Federal University of Uberlândia. 


\section{References}

Aggarwal, P., \& Dollimore, D. (1998). A thermal analysis investigation of partially hydrolyzed starch. Thermochimica Acta, 319(1-2), 17-25.

Andrade Silva, S., de Souza Laranjeira, A. C., Velozo, C., Montenegro, L. D. A. S., Bernardo, B. B. B., da Silva Santos, M. B., \& de Albuquerque, D. S. (2021). Regeneração após cirurgia paraendodôntica em dente com extensa fenestração óssea-Relato de caso com acompanhamento de 3 anos. Research, Society and Development, 10(4), e22210413983-e22210413983.

Becker, W., Becker, B. E., Caffesse, R., Kerry, G., Ochsenbein, C., Morrison, E., \& Prichard, J. (2001). A longitudinal study comparing scaling, osseous surgery, and modified Widman procedures: results after 5 years. Journal of periodontology, 72(12), 1675-1684.

Böstman, O. M. (1992). Intense granulomatous inflammatory lesions associated with absorbable internal fixation devices made of polyglycolide in ankle fractures. Clinical orthopaedics and related research, (278), 193-199.

Boyne, P. J. (1964). Regeneration of alveolar bone beneath cellulose acetate filter implants. J Dent Res, $43,827$.

Boyne, P. J. (1969). Restoration of osseous defects in maxillofacial casualties. The Journal of the American Dental Association, 78(4), 767-776.

Chang, Y. P., Abd Karim, A., \& Seow, C. C. (2006). Interactive plasticizing-antiplasticizing effects of water and glycerol on the tensile properties of tapioca starch films. Food Hydrocolloids, 20(1), 1-8.

Chen, Y. T., Wang, H. L., Lopatin, D. E., O'Neal, R., \& MacNeil, R. L. (1997). Bacterial adherence to guided tissue regeneration barrier membranes exposed to the oral environment. Journal of periodontology, 68(2), 172-179.

Cruz, J. C., Koester, D. L., Deon, V. G., Biduski, B., de Amorin, S. G., Quast, L. B., \& Pinto, V. Z. (2020). Bandejas expandidas de amido de batata reforçadas com bagaço de malte. Research, Society and Development, 9(9), e875997630-e875997630.

Doulabi, A. H., Mirzadeh, H., Imani, M., \& Samadi, N. (2013). Chitosan/polyethylene glycol fumarate blend film: Physical and antibacterial properties. Carbohydrate polymers, $92(1), 48-56$.

Gerzson, A. S., Ribeiro Júnior, P. D., Matsumoto, M. A., Duarte, M. A. H., \& Weckwerth, P. H. (2016). Barrier membranes for GBR: characteristics and indication. J Clin Dent Res, 13, 120-125.

Gontijo de Melo, P., Fornazier Borges, M., Afonso Ferreira, J., Vicente Barbosa Silva, M., \& Ruggiero, R. (2018). Bio-based cellulose acetate films reinforced with lignin and glycerol. International journal of molecular sciences, 19(4), 1143.

Gottlow, J., Nyman, S., Lindhe, J., Karring, T., \& Wennström, J. (1986). New attachment formation in the human periodontium by guided tissue regeneration Case reports. Journal of clinical periodontology, 13(6), 604-616. Hollinger, J., \& Chaudhari, A. (1992). Bone regeneration materials for the mandibular and craniofacial complex. Cells and Materials, 2(2), 9.

Hurley, L. A., Stinchfield, F. E., Bassett, C. A. L., \& Lyon, W. H. (1959). The role of soft tissues in osteogenesis: An experimental study of canine spine fusions. JBJS, 41(7), 1243-1266.

Jane, J. L. (2006). Current understanding on starch granule structures. Journal of Applied Glycoscience, 53(3), $205-213$.

Jaramillo, C. M., Gutiérrez, T. J., Goyanes, S., Bernal, C., \& Famá, L. (2016). Biodegradability and plasticizing effect of yerba mate extract on cassava starch edible films. Carbohydrate polymers, 151, 150-159.

Karring, T., Isidor, F., Nyman, S., \& Lindme, J. (1985). New attachment formation on teeth with a reduced but healthy periodontal ligament. Journal of clinical periodontology, 12(1), 51-60.

Kawabata, A., Sawayama, S., Nagashima, N., del Rosario, R. R., \& Nakamura, M. (1984). Some physico-chemical properties of starches from cassava, arrowroot and sago. Journal of the Japanese Society of Starch Science, 31(4), 224-232.

Kim, M., \& Lee, S. J. (2002). Characteristics of crosslinked potato starch and starch-filled linear low-density polyethylene films. Carbohydrate polymers, 50(4), $331-337$.

Kohavi, D., Pollack, S. R., Brighton, G., \& Bulkin, B. (1991). Surgically modelled reduced ridge in the beagle dog. Clinical oral implants research, 2(3), 145150 .

Kou, T., \& Gao, Q. (2018). New insight in crosslinking degree determination for crosslinked starch. Carbohydrate research, $458,13-18$.

Linde, A., Alberius, P., Dahlin, C., Bjurstam, K., \& Sundin, Y. (1993). Osteopromotion: A soft-tissue exclusion principle using a membrane for bone healing and bone neogenesis. Journal of periodontology, 64, 1116-1128.

Menzel, C., Olsson, E., Plivelic, T. S., Andersson, R., Johansson, C., Kuktaite, R., \& Koch, K. (2013). Molecular structure of citric acid cross-linked starch films. Carbohydrate polymers, $96(1), 270-276$.

Moad, G. (2011). Chemical modification of starch by reactive extrusion. Progress in Polymer Science, 36(2), 218-237.

Moorthy, S. N. (2002). Physicochemical and functional properties of tropical tuber starches: a review. Starch-Stärke, 54(12), 559-592.

Müller, C. M., Yamashita, F., \& Laurindo, J. B. (2008). Evaluation of the effects of glycerol and sorbitol concentration and water activity on the water barrier properties of cassava starch films through a solubility approach. Carbohydrate Polymers, 72(1), 82-87. 
Nyman, S., Linde, J., \& Karring, T. (1989). Reattachment- new attachment.In: Lindhe J. Textbook of Clinical Periodontology. ed. 2 Copenhagen: Munksgard, $450-476$.

Pecora, G., Baek, S. H., Rethnam, S., \& Kim, S. (1997). Barrier membrane techniques in endodontic microsurgery. Dental Clinics of North America, 41(3), 585602.

Pinheiro, J. C., da Fonseca Neto, B., da Cruz Lima, J. G., Silva, Y. A., da Silva, G. G., Morais, I. P. S., \& Almeida, D. R. D. M. F. (2021). Use of biomaterials in the surgical regenerative treatment of peri-implantitis: systematic review. Research, Society and Development, 10(12), e275101220454-e275101220454.

Rengadu, D., Gerrano, A. S., \& Mellem, J. J. (2020). Physicochemical and structural characterization of resistant starch isolated from Vigna unguiculata. International journal of biological macromolecules, 147, 268-275.

Rocha, T. S., Demiate, I. M., \& Franco, C. M. L. (2008). Características estruturais e físico-químicas de amidos de mandioquinha-salsa (Arracacia xanthorrhiza). Food Science and Technology, 28(3), 620-628.

Rothamel, D., Schwarz, F., Sager, M., Herten, M., Sculean, A., \& Becker, J. (2005). Biodegradation of differently cross-linked collagen membranes: an experimental study in the rat. Clinical oral implants research, 16(3), 369-378.

Schwarz, F., Rothamel, D., Herten, M., Sager, M., \& Becker, J. (2006). Angiogenesis pattern of native and cross-linked collagen membranes: An immunohistochemical study in the rat. Clinical oral implants research, 17(4), 403-409.

Schwarz, F., Rothamel, D., Herten, M., Wüstefeld, M., Sager, M., Ferrari, D., \& Becker, J. (2008). Immunohistochemical characterization of guided bone regeneration at a dehiscence-type defect using different barrier membranes: an experimental study in dogs. Clinical oral implants research, 19(4), 402-415.

Shi, R., Bi, J., Zhang, Z., Zhu, A., Chen, D., Zhou, X., ... \& Tian, W. (2008). The effect of citric acid on the structural properties and cytotoxicity of the polyvinyl alcohol/starch films when molding at high temperature. Carbohydrate polymers, 74(4), 763-770.

Silva, L. S. C., Martim, S. R., Gomes, D. M. D., Prado, F. B., Marinho, N. M. V., de Amorim Silva, T., \& Teixeira, M. F. S. (2021). Amazonian tuber starch based films incorporated with silver nanoparticles for preservation of fruits. Research, Society and Development, 10(6), e23510615304-e23510615304.

Singh, J., Kaur, L., \& McCarthy, O. J. (2007). Factors influencing the physico-chemical, morphological, thermal and rheological properties of some chemically modified starches for food applications-A review. Food hydrocolloids, 21(1), 1-22.

Somerman, M. J., Sauk, J. J., Foster, R. A., Norris, K., Dickerson, K., \& Argraves, W. S. (1991). Cell attachment activity of cementum: bone sialoprotein identified in cementum. Journal of periodontal research, 26(1), 10-16.

Srinivasa, P. C., Ramesh, M. N., \& Tharanathan, R. N. (2007). Effect of plasticizers and fatty acids on mechanical and permeability characteristics of chitosan films. Food hydrocolloids, 21(7), 1113-1122.

Thiebaud, S., Aburto, J., Alric, I., Borredon, E., Bikiaris, D., Prinos, J., \& Panayiotou, C. (1997). Properties of fatty-acid esters of starch and their blends with LDPE. Journal of Applied Polymer Science, 65(4), 705-721.

Warrer, K., Gotfredsen, K., Hjsrting-hansen, E., \& Karring, T. (1991). Guided tissue regeneration ensures osseointegration of dental implants placed into extraction sockets. An experimental study in monkeys. Clinical Oral Implants Research, 2(4), 166-171.

Williams, D. F. (1981). Biomaterials and biocompatibility: An introduction. In: Williams DF. Fundamental Aspects of Biocompatibility, vol 1. Boca Raton, FL: CRC Press.

Wolkers, W. F., Oliver, A. E., Tablin, F., \& Crowe, J. H. (2004). A Fourier-transform infrared spectroscopy study of sugar glasses. Carbohydrate research, 339(6), 1077-1085.

Wu, H., Lei, Y., Lu, J., Zhu, R., Xiao, D., Jiao, C., ... \& Li, M. (2019). Effect of citric acid induced crosslinking on the structure and properties of potato starch/chitosan composite films. Food Hydrocolloids, 97, 105208.

Zaia, D. A., Zaia, C. T. B., \& Lichtig, J. (1998). Determinação de proteínas totais via espectrofometria: vantagens e desvantagens dos métodos existentes. Química nova, 21, 787-793. 